\title{
Cellular models for disease exploring and drug screening
}

\author{
Zhi-kun Li ${ }^{1,2}$, Qi Zhou ${ }^{1 凶}$ \\ ${ }^{1}$ State Key Laboratory of Reproductive Biology, Institute of Zoology, Chinese Academy of Sciences, Beijing 100101, China \\ ${ }^{2}$ Graduate School, Chinese Academy of Sciences, Beijing 100049, China \\ $\triangle$ Correspondence: qzhou@ioz.ac.cn \\ Received November 17, 2009 Accepted January 21, 2010
}

\begin{abstract}
The biopharmaceutical industry has been greatly promoted by the application of drug and disease models, including both animal and cellular models. In particular, the emergence of induced pluripotent stem cells (iPSC) makes it possible to create a large number of diseasespecific cells in vitro. This review introduces the most widely applied models and their specialties.
\end{abstract}

KEYWORDS cellular models, disease models, induced pluripotential stem cells, neural diseases

\section{INTRODUCTION}

It has been a long history since people declared war on disease. The manuscript Shen Nong Ben Cao Jing in ancient China represents the permanent aspiration of humans: to understand and cure diseases. Due to the prosperity of life science in the last two centuries, an increasing number of diseases have been conquered, such as variola and tuberculosis, and drug and disease models played an indispensable role in the process. It is worth mentioning that some recently emerged techniques have breathed new life into this old field.

\section{THE ANIMAL MODELS OF DRUGS AND DISEASES}

Since etiological pioneers vaccinated mice with the serum derived from smallpox patients in the 19th century, animal models have been playing a vital role in the field of biomedical study. Vertebrate models, including rodents or livestock, are extensively used in disease and drug research. With the development of model construction techniques, a growing number of diseases can be simulated and investigated with animals. However, the limitation of the animal model reveals itself when further study is required.
The comparison of the mouse and the human genome has revealed that more than $80 \%$ of mouse genes have bidirectional homologues in the human genome (Waterston et al., 2002), indicating the rationality of using the mouse as a human disease model. Nevertheless, the $20 \%$ of differences has hindered the usage of the mouse model, which does not accurately recapitulate the human disease phenotype. For example, the mutated HPRT1 gene leads to Lesch-Nyhan syndrome that is tied to neurological abnormalities; however, the mice model with the homologous mutation causes excessive uric acid and renal calculus (Stout and Caskey, 1988). In addition, some mutations of disease homologous genes result in non-visual phenotype change in the mouse model (Cartwright, 2009). Other laboratory animals, such as rats or non-human primates, are thought to be better alternatives, but the limitation still exists.

Because the genetic differences between human and animal may cause diverse phenotypes, a number of diseases cannot be properly simulated with animals. The application is also hindered by the heterogeneity and complexity of animal models. The phenotype changes or the therapeutic effects in animal models are not always authentic representations of human physiological conditions. For example, a large number of neurological diseases can be simulated in rodents, but only few of them can precisely represent the human syndrome at molecular or anatomical level (Jakel et al., 2004). In addition, the construction and utilization of animal models may lead to ethical disputations.

\section{ADULT DERIVED CELL MODELS OF DRUGS AND DISEASES}

\section{Somatic cell models}

Cellular models can partially complement the disadvantages of animal models. Traditionally, primary cells can be used in 
pathological study, drug screening or toxicity tests at cellular or molecular level (Jakel et al., 2004; Sundstrom et al., 2005). The utilization of human cells makes it possible to understand diseases in a genuine human source medium rather than non-human origin substitutes. Nevertheless, the model is far from perfect. Some primary cells are characterized by a low proliferative capacity associated with a rapid decline of differentiation ability during subculturing, which thereby limits their use (Darimont, 2003). Furthermore, there are abundant diseases caused by the physiological abnormality of cardiac muscle, cerebra or spinal cord, but samples from those spots are hard to take. A practicable alternative to model these diseases is to transfer pathogenic mutated genes into available cell lineages. The disease- related events, such as cell senescence or cell cycle changes, can be mimicked (Brown et al., 1997; Bunz et al., 1998). Using this rationale, cell lines expressing G-protein coupled receptors (GPCR) can be used for drug screening (Zeh et al., 2003). However, the relatively low efficiency has hampered the application of these models (Zeh et al., 2003; Schneider et al., 2007). Another limitation of the cellular model comes from its superiority: as an in vitro model, it is not influenced by intracorporal factors such as circulatory system or immune system. Accordingly, the animal model still plays an indispensable role in drug screening and disease study. Some new approaches, such as human-animal chimeras, can model diseases in vivo with human tissues. They are generated by grafting human embryonic stem cells (hESCs) or hESC-derived cells into immune-deficient mice (Saha and Jaenisch, 2009). Although the hESCs are differentiated and functional after injection into fetal mice, it is not clear whether these cells are identical in all aspects with human cells because the cells have experienced non-human circulation system or microenvironment.

\section{Immortalized cell models and the applications}

Given that primary cells cannot stably proliferate, a series of immortalized cell models are constructed by ectopic oncogene or telomerase gene transduction, or a combination of both (Obinata, 2007). The immortalized cells derived from human or animals may solve the resource limitation of primary cells (Darimont, 2003; Obinata, 2007; Pang et al., 2008), what is more, the immortalization test is currently used as a risky assessment procedure of drug candidates (Landolph, J.R., 2006; Pang et al., 2008).

Unlike primary cells, which lose their original characteristics during the process of in vitro proliferation, immortalized cell models may lack some characters from the beginning (Jensen et al., 2009). Furthermore, only a small amount of human-origin immortalized cell models are available, whereas animal origin cell models are less efficient due to the species difference.

\section{Patient-specific multipotent cell models}

Patient-specific multipotent cells, including cord blood origin stem cells (Theoharides et al., 2006) and adult stem cells (Jakel et al., 2004; Dan and Yeoh, 2008; Buzanska et al., 2009), are better disease model candidates compared with primary or immortalized cells. Disease-specific cells can facilitate the study of disease-related genes and provide a platform to investigate the relationship between differentiation and pathogenesis. Adult stem cells or cord blood stem cells are self-renewable. More importantly, they are able to differentiate in vitro (Dan and Yeoh, 2008; Buchheiser et al., 2009; Patel et al., 2009; Simon et al., 2009), providing more cells compared with primary culture. However, the differentiation capacity of patient-derived multipotent cells might be weakened under in vitro culture conditions (Wright et al., 2006).

\section{HUMAN EMBRYONIC STEM CELL MODELS OF DRUGS AND DISEASES}

Established in 1998, hESCs are thought to be promising candidates in regenerative medicine or as cell models (Thomson et al., 1998). The infinite passaging potential of hESCs provides abundant cells that can be used in disease research and drug screening (Sartipy et al., 2007; Jensen et al., 2009). As an ideal model for in vitro differentiation, the pluripotent embryonic stem cell recapitulates the cellular developmental processes and gene expression patterns of early embryogenesis, which may benefit the embryotoxicity study of drugs (Rohwedel et al., 2001).

The hepatic cell model is used as a golden standard in testing drug metabolism and toxicity (Cross and Bayliss, 2000; Kola and Landis, 2004). However, the most commonly applied hepatic cell models today are derived from transformed hepatocytes, such as HepG2. These cell lines have obvious defects due to the transformed phenotype (Sartipy et al., 2007; Jensen et al., 2009). In contrast, hepatic cells derived from $\mathrm{hESC}$ are much closer to genuine hepatocytes than hepatoma carcinoma cells (Yamada et al., 2002).

Cardiomyocyte toxicity is a common side effect of a variety of drugs, which makes cardiomyocyte models indispensible in developing cardiac drugs (Norstrom et al., 2006). Primary human cardiomyocytes may rapidly lose functional properties when cultured in vitro (Sartipy et al., 2007). However, the existing cardiomyocyte models derived from non-human origins are different from human cardiomyocytes (Cross and Bayliss, 2000). On the other hand, new opportunities have emerged due to the generation of cardiac progenitors and multiple types of cardiac myocytes from hESCs (Norstrom et al., 2006; Tanaka, 2009).

Investigating postmortem brain tissue from affected patients provides information about the pathogenesis of mutant proteins and toxins in neurological diseases (Jakel 
et al., 2004). Nevertheless, due to the limited proliferative capability of neurocytes, it is hard to model neural diseases by cell cultures (Jakel et al., 2004). Fortunately, much knowledge of neural differentiation has been accumulated after the establishment of hESCs. Neurons, gliocytes and their progenitors can be acquired via in vitro differentiation of hESCs (Sartipy et al., 2007). These achievements, together with the existing cell model techniques, laid the foundation for the possible application of hESCs as an alternative source of neurocyte models.

Genetically modified hESCs have particular application on simulating disease-specific cell models (Ben-Nun and Benvenisty, 2006). For example, dopamine neurons derived from $\alpha$ synuclein over-expressed hESCs possess distinct Parkinson's characteristics (Schneider et al., 2007). Such neurons are an appropriate source of a Parkinson's disease model; however, the over-expressed $\alpha$-synuclein elicits more toxicity in hESC-derived dopaminergic neurons than in primary neurons (Schneider et al., 2007). Nowadays, the three most widely used techniques in cellular model construction of human disorders are homologous recombination, gene trap and RNA interference (Ben-Nun and Benvenisty, 2006), but these methods are only applicable to the well-characterized diseases.

Disease-specific hESCs can be derived from cloned embryos or preimplantation genetically diagnosed (PGD) embryos (Ben-Nun and Benvenisty, 2006). However, there is no authentic report to date of hESCs created by somatic cell nuclear transfer (SCNT), and the numbers of PGD embryos are extremely limited. More importantly, both methods face ethical dilemmas.

As an in vitro model system, hESCs and their derivatives are not able to provide accurate information to some long latency or complex diseases. Thus, a human-animal chimera model system is required as an in vivo alternative (Saha and Jaenisch, 2009). Humanized animal models are generated by direct injection of hESCs into mice brain (Muotri et al., 2005; Acharya et al., 2009), and then functional neural lineages are formed and integrated into the brain. The chimeric model allows the study of human neural development in a live environment, paving the way for generating new models of human neurodegenerative and psychiatric diseases (Muotri et al., 2005). However, human-animal chimeras are not perfect because the mouse microenvironment may have unexpected effects on the human cells. In addition, the application of chimera models may lead to ethical conflicts because some people think that generating chimeras crosses the boundary between human and animal (Hyun et al., 2007).

\section{INDUCED PLURIPOTENTIAL STEM CELL MODELS OF DRUGS AND DISEASES}

The emergence of induced pluripotent stem cells (iPSCs) makes it more exercisable to get large numbers of disease-specific cells in vitro. The iPSC technique requires the expression of an ectopic transcriptional factors cocktail in somatic cells, which leads to the reprogramming of somatic cells to a pluripotent state (Takahashi and Yamanaka, 2006; Takahashi et al., 2007; Yu et al., 2007). After this technical breakthrough, significant progress in improving the safety and efficiency of iPSC induction has been made, leading to a further step towards the future application of iPSCs in regeneration medicine (Okita et al., 2008; Stadtfeld et al., 2008; Hanna et al., 2009; Yu et al., 2009; Zhou et al., 2009). Recently, mouse iPSCs have passed the most stringent tetraploid complementation assay, which undoubtedly confirmed the pluripotency of iPSCs in vivo for the first time (Zhao et al., 2009). It is shown that iPSCs share identical differentiation capacity with ESCs. On the other hand, increasing evidence shows that iPSCs and ESCs are distinguishable at epigenetic or transcriptional levels (Chin et al., 2009; Huang et al., 2009; Sridharan et al., 2009), although the differences might be due to the imperfect reprogramming state rather than the congenital defects of iPSCs (Chan et al., 2009; Silva et al., 2009; Smith, 2009).

There are also natural reprogramming processes in vivo. For example, several reprogramming events occur in germ cells on the road toward totipotency. In particular, when primordial germ cells (PGCs) migrate into developing gonads on E11.5, they undergo extensive epigenetic modifications, including genome-wide DNA demethylation, removal of imprints and reactivation of the $\mathrm{X}$ chromosome (Hajkova et al., 2002, 2007, 2008; Surani et al., 2008). The processes can be mimicked in vitro as the dedifferentiation of PGCs into pluripotent embryonic germ (EG) cells (Matsui et al., 1992; Surani et al., 2008). Recently, the epigenetic reversion of post-implantation epiblast to pluripotent embryonic stem cells shows that the reprogramming course PGC went through on E11.5 can be mimicked in non-germline cells (Bao et al., 2009). Further studies on the natural reprogramming processes may give clues to the underlying mechanism of the iPSC technique and the use of safer methods to induce somatic cells into a pluripotent state in future.

iPSCs derived from the patient's somatic cells have high immunological compatibility, which makes them a powerful competitor of hESCs in regeneration medicine field. Another major application of iPSCs is to be an in vitro disease model due to their broad resources and similarity to hESCs. In addition, the iPSC technique facilitates the construction of model panel covering a variety of genetic origins (Tanaka et al., 2009). Most importantly, disease-specific pluripotent cells can be derived from the patient's somatic cells directly. Approximately $10 \%$ of patients with amyotrophic lateral sclerosis, $7 \%$ with early-onset Alzheimer's disease, and less than $1 \%$ with Parkinson's disease are believed to have familial variants, and only a subset of these patients carry known mutations (Koch et al., 2009). Patient-derived iPSCs can remarkably facilitate the modeling of these diseases.

Human iPSCs (hiPSCs) can be used in embryotoxicity 
tests or disease-related studies during the differentiation processes in vitro. Among the transcription factors used in induction of iPSCs, c-Myc is also used in immortalized cell models. Interestingly, although c-Myc is dispensable during in vitro reprogramming (Nakagawa et al., 2008), the acquisition of immortality is a crucial and rate-limiting step towards the establishment of iPSCs (Utikal et al., 2009).

The advances mentioned above do not obviate the need for hESCs (Insoo Hyun, 2007). It is reported that the trace expression of exogenetic transcriptional factors may influence the state and differential capacity of iPSCs (Yu et al., 2007; Soldner et al., 2009). In addition, there are also differences between hiPSCs and hESCs in terms of the epigenetic state of both nuclear genome and mitochondrial genome (Chamberlain et al., 2008; Ying et al., 2008). It is reported that more than 1200 genes are differently expressed in hESCs and hiPSCs (Takahashi et al., 2007). The differences may be due to the imperfect reprogramming of hiPSCs, but it is also possible that the hESCs used as comparison do not represent the authentic embryonic stem cell state (Brons et al., 2007; Tesar et al., 2007; Silva et al., 2009; Vallier et al., 2009). On the other hand, as another in vitro system, hiPSCs cannot provide accurate information on some long latency or complicated diseases. Unlike hESCs, there is no report so far of using hiPSCs or their derivatives to construct a human-animal chimera.

In spite of the existing disadvantages, hiPSCs are still promising models for drug development and disease studies. Recently, the generation of patient-specific iPSCs has been successfully applied to several neurological disorders (Dimos et al., 2008; Park et al., 2008; Ebert et al., 2009; Lee et al., 2009; Maehr et al., 2009; Raya et al., 2009; Soldner et al., 2009). iPSCs from spinal muscular atrophy patient are able to differentiate into motor neurons in vitro, but with less number and smaller size compared with normal iPSC-derived counterparts. The SMN1 gene in these motor neurons is less expressed, and the formation of synapse is delayed (Ebert et al., 2009). These details involved in developmental process can be provided by disease-specific iPSCs or the PGD embryo-derived hESCs, while the former one is much easier to obtain.

Human iPSCs have also proved their potency as drug screening models. Tachycardia is the common side effect of heart disease medicines and is an important parameter in the drug safety assessment. Nevertheless, there is no practicable human cardiomyocyte model that can be used to evaluate heart disease drugs (Sartipy et al., 2007). Functional cardiomyocytes derived from hiPSCs have similar expression pattern and contractile function compared with normal counterparts. These cardiomyocytes are sensitive to a range of cardiopathy medicines. This study shows that hiPSC-derived cardiomyocytes are promising as an in vitro model for cardiac drug screening (Tanaka et al., 2009).

Familial dysautonomia (FD) is a fatal autosomal degenerative disease characterized by the degeneration of sensory and autonomic neurons. The disease is caused by the inaccurate splicing of the IKBKAP transcription product. Gabsang Lee and colleagues used FD patient-derived hiPSCs to generate the disease-specific neurons in vitro. They found a co-existence of both correct and incorrect splicing pattern in these neurons. Furthermore, the plant hormone kinetin can reduce the proportion of incorrect splicing (Lee et al., 2009). This study provides new insights into disease pathogenesis and suggests alternative functional assays for the identification and validation of drug candidates for the first time.

\section{NEURAL DIFFERENTIATION OF PLURIPOTENT CELLS AND NEURAL DISEASES}

There are hundreds of nervous system-related diseases. The most common ones include Parkinson's disease, Alzheimer's disease and ataxias. Therefore, neural differentiation is one of the most attractive subjects in the area of in vitro differentiation of embryonic stem cells or iPSCs. Tremendous efforts have been exerted in the field of neural differentiation and numerous accomplishments have been achieved.

The approaches to acquire neurocytes from ESCs can be divided into three categories. Upon the aggregation to embryoid bodies (EBs), differentiating ESCs can be induced into neural precursors, from which different kinds of neurons can be acquired (Bain et al., 1995; Zhang et al., 2001). This method is based on the simulation of the early neural development process in vivo (Chamberlain et al., 2008). Alternatively, neurons can be obtained from ESCs through the induction of midbrain dopaminergic neurons by stromal cell-derived inducing activity (Kawasaki et al., 2000). Since a high proportion of midbrain cells can be generated, this approach is widely used to induce dopaminergic neurons (Kawasaki et al., 2000). The adherent monoculture system provides a platform for defining the molecular machinery of neural commitment and for optimizing the efficiency of neuronal and glial cell production from ESCs (Ying et al., 2003).

\section{DRUG DISCOVERY AND TARGET IDENTIFICATION}

Generating appropriate cellular models has significant impacts on drug screening. There are three major sources of modern drugs: natural products, combinatorial chemicals and the derivatives of existing drugs (Feher and Schmidt, 2003). Among the 974 drugs approved by the Food and Drug Administration (FDA) from 1984 to 2007, 63\% are natural products or their derivatives (Newman and Cragg, 2007). Combinatorial chemicals are designed to bind specific drug targets. The interaction between drugs and their targets may induce the conformation and activity changes of the targets. This method requires an in-depth comprehension of disease mechanism (Dixon and Stockwell, 2009). Furthermore, there 
Table 1 The characteristics of different drug and disease models

\begin{tabular}{lcc}
\hline models & advantages & disadvantages \\
\hline animal model & $\begin{array}{c}\text { in vivo experiment variety of strategies variety } \\
\text { of animals plenty of experiences }\end{array}$ & $\begin{array}{c}\text { differences between human and animals } \\
\text { limited applications the complexity of } \\
\text { models ethics disputes }\end{array}$ \\
$\begin{array}{l}\text { primary cell culture model } \\
\text { immortalized cell model }\end{array}$ & $\begin{array}{c}\text { disease specific easy to obtain } \\
\text { stable proliferation disease specific cells } \\
\text { can be obtained }\end{array}$ & $\begin{array}{c}\text { in vitro experiment difficult to proliferate } \\
\text { cell transformation }\end{array}$ \\
$\begin{array}{l}\text { patient specific pluripotent } \\
\text { cell model }\end{array}$ & $\begin{array}{c}\text { disease specific differentiation capacity } \\
\text { relatively stable proliferation } \\
\text { human embryonic stem } \\
\text { cell model } \\
\text { induced pluripotent stem } \\
\text { cell model }\end{array}$ & $\begin{array}{c}\text { pluripotent stable proliferation genetic } \\
\text { modifiable embryotoxicity study }\end{array}$ \\
\hline
\end{tabular}

are only $10 \%-15 \%$ of human genes that can be affected by drugs, limiting the number of drugable targets (Dixon and Stockwell, 2009). The simplest approach to treat a genetic disorder is to directly modulate the function of a diseasecausing gene product by small chemicals (van de Ven et al., 2007; Dixon and Stockwell, 2009). Alternatively, indirect targets can be selected with the knowledge of diseaseassociated biological processes when the disease-causing gene product is indrugable (Dixon and Stockwell, 2009; Soucy et al., 2009). These approaches can be facilitated by cellular models. For example, the study of tumor cells reveals that nutlin protects p53 by destroying the interaction between Mdm2 and p53, which leads to the apoptosis of tumor cells (Vassilev et al., 2004). Further knowledge of hiPSCs in the future may give new insights into the drug discovery strategies.

\section{SUMMARY}

The emergence of hiPSCs may give solution to a long-term barrier of the application of cellular models: the generation of disease-specific cells. Previous models are limited by their multiple defects, such as the unstable proliferation or nonspecificity. Patient-derived hiPSCs, which can proliferate and differentiate in vitro, have a good promise in disease modeling (Table 1). As the iPSC technique becomes increasingly efficient and effective, safer iPSCs will be obtained. The neural disease model is one of the most intriguing applications of hiPSCs because some most common neurological disorders are genetically related and hard to be modeled alternatively. It is predictable that the development of hiPSC models will substantially promote the study of neural diseases and drug screening.

\section{ACKNOWLEDGEMENTS}

We thank Dr. Duanqing Pei for reviewing the manuscript prior to submission. This study was supported in part by the China National
Basic Research Program (Grant No. 2006CB701501) and the National Natural Science Foundation of China (Grant No. 30525040).

\section{ABBREVIATIONS}

EB, embryoid body; EG, embryonic germ; FD, familial dysautonomia; GPCR, G-protein coupled receptors; ESC, embryonic stem cell; iPSC, induced pluripotent stem cell; PGC, primordial germ cell; PGD, preimplantation genetically diagnosed; SCNT, somatic cell nuclear transfer

\section{REFERENCES}

Acharya, M.M., Christie, L.A., Lan, M.L., Donovan, P.J., Cotman, C. W., Fike, J.R., and Limoli, C.L. (2009). Rescue of radiation-induced cognitive impairment through cranial transplantation of human embryonic stem cells. Proc Natl Acad Sci U S A 106, 19150-19155.

Bain, G., Kitchens, D., Yao, M., Huettner, J.E., and Gottlieb, D.I. (1995). Embryonic stem cells express neuronal properties in vitro. Dev Biol 168, 342-357.

Bao, S., Tang, F., Li, X., Hayashi, K., Gillich, A., Lao, K., and Surani, M.A. (2009). Epigenetic reversion of post-implantation epiblast to pluripotent embryonic stem cells. Nature 461, 1292-1295.

Ben-Nun, I.F., and Benvenisty, N. (2006). Human embryonic stem cells as a cellular model for human disorders. Mol Cell Endocrinol 252, 154-159.

Brons, I.G., Smithers, L.E., Trotter, M.W., Rugg-Gunn, P., Sun, B., Chuva de Sousa Lopes, S.M., Howlett, S.K., Clarkson, A., AhrlundRichter, L., Pedersen, R.A., et al. (2007). Derivation of pluripotent epiblast stem cells from mammalian embryos. Nature 448, 191-195.

Brown, J.P., Wei, W., and Sedivy, J.M. (1997). Bypass of senescence after disruption of p21CIP1/WAF1 gene in normal diploid human fibroblasts. Science $277,831-834$.

Buchheiser, A., Liedtke, S., Looijenga, L.H., and Kogler, G. (2009). Cord blood for tissue regeneration. J Cell Biochem 108, 762-768.

Bunz, F., Dutriaux, A., Lengauer, C., Waldman, T., Zhou, S., Brown, J. P., Sedivy, J.M., Kinzler, K.W., and Vogelstein, B. (1998). Requirement for $p 53$ and $p 21$ to sustain $G 2$ arrest after DNA 
damage. Science 282, 1497-1501.

Buzanska, L., Sypecka, J., Molteni, S.N., Compagnoni, A., Hogberg, H.T., Del Torchio, R., Domanska-Janik, K., Zimmer, J., and Coecke, S. (2009). A human stem cell based model for identifying adverse effects of organic and inorganic chemicals on the developing nervous system. Stem Cells 27, 2591-2601.

Cartwright, E.J. (2009). Large-scale mouse mutagenesis. Methods Mol Biol 561, 275-283.

Chamberlain, S.J., Li, X.J., and Lalande, M. (2008). Induced pluripotent stem (iPS) cells as in vitro models of human neurogenetic disorders. Neurogenetics 9, 227-235.

Chan, E.M., Ratanasirintrawoot, S., Park, I.H., Manos, P.D., Loh, Y.H., Huo, H., Miller, J.D., Hartung, O., Rho, J., Ince, T.A., et al. (2009). Live cell imaging distinguishes bona fide human iPS cells from partially reprogrammed cells. Nat Biotechnol 27, 1033-1037.

Chin, M.H., Mason, M.J., Xie, W., Volinia, S., Singer, M., Peterson, C., Ambartsumyan, G., Aimiuwu, O., Richter, L., Zhang, J., et al. (2009). Induced pluripotent stem cells and embryonic stem cells are distinguished by gene expression signatures. Cell Stem Cell 5 , 111-123.

Cross, D.M., and Bayliss, M.K. (2000). A commentary on the use of hepatocytes in drug metabolism studies during drug discovery and development. Drug Metab Rev 32, 219-240.

Dan, Y.Y., and Yeoh, G.C. (2008). Liver stem cells: A scientific and clinical perspective. J Gastroenterol Hepatol 23, 687-698.

Darimont, C. (2003). Immortalization of human preadipocytes. Biochimie 85, 1231-1233.

Dimos, J.T., Rodolfa, K.T., Niakan, K.K., Weisenthal, L.M., Mitsumoto, H., Chung, W., Croft, G.F., Saphier, G., Leibel, R., Goland, R., et al. (2008). Induced pluripotent stem cells generated from patients with ALS can be differentiated into motor neurons. Science 321, 1218-1221.

Dixon, S.J., and Stockwell, B.R. (2009). Identifying druggable disease-modifying gene products. Curr Opin Chem Biol 13, 549-555.

Ebert, A.D., Yu, J., Rose, F.F., Jr., Mattis, V.B., Lorson, C.L., Thomson, J.A., and Svendsen, C.N. (2009). Induced pluripotent stem cells from a spinal muscular atrophy patient. Nature 457 , 277-280.

Feher, M., and Schmidt, J.M. (2003). Property distributions: differences between drugs, natural products, and molecules from combinatorial chemistry. J Chem Inf Comput Sci 43, 218-227.

Hajkova, P. (2007). Genetic and epigenetic regulators of pluripotency. Cell 128, 747-762

Hajkova, P., Ancelin, K., Waldmann, T., Lacoste, N., Lange, U.C., Cesari, F., Lee, C., Almouzni, G., Schneider, R., and Surani, M.A. (2008). Chromatin dynamics during epigenetic reprogramming in the mouse germ line. Nature 452, 877-881.

Hajkova, P., Erhardt, S., Lane, N., Haaf, T., El-Maarri, O., Reik, W., Walter, J., and Surani, M.A. (2002). Epigenetic reprogramming in mouse primordial germ cells. Mech Dev 117, 15-23.

Hanna, J., Saha, K., Pando, B., van Zon, J., Lengner, C.J., Creyghton, M.P., van Oudenaarden, A., and Jaenisch, R. (2009). Direct cell reprogramming is a stochastic process amenable to acceleration. Nature 462, 595-601.

Huang, J.Y., Chen, T.T., Liu, X.S., Jiang, J., Li, J.S., Li, D.S., Liu, X.S., Li, W., Kang, J.H., and Pei, G. (2009). More synergetic cooperation of Yamanaka factors in induced pluripotent stem cells than in embryonic stem cells. Cell Res 19, 1127-1138.

Hyun, I., Taylor, P., Testa, G., Dickens, B., Jung, K.W., McNab, A., Robertson, J., Skene, L., and Zoloth, L. (2007). Ethical standards for human-to-animal chimera experiments in stem cell research. Cell Stem Cell 1, 159-163.

Insoo Hyun, K.H., Rudolf Jaenisch, and Shinya Yamanaka (2007). New advances in iPS cell research do not obviate the need for human embryonic stem cells. Cell Stem Cell 11, 367-368.

Jakel, R.J., Schneider, B.L., and Svendsen, C.N. (2004). Using human neural stem cells to model neurological disease. Nature Rev Genet 5, 136-144.

Jensen, J., Hyllner, J., and Bjorquist, P. (2009). Human embryonic stem cell technologies and drug discovery. J Cell Physiol 219, 513-519.

Kawasaki, H., Mizuseki, K., Nishikawa, S., Kaneko, S., Kuwana, Y., Nakanishi, S., Nishikawa, S.I., and Sasai, Y. (2000). Induction of midbrain dopaminergic neurons from ES cells by stromal cellderived inducing activity. Neuron 28, 31-40.

Koch, P., Kokaia, Z., Lindvall, O., and Brustle, O. (2009). Emerging concepts in neural stem cell research: autologous repair and cellbased disease modelling. Lancet Neurol 8, 819-829.

Kola, I., and Landis, J. (2004). Can the pharmaceutical industry reduce attrition rates? Nat Rev Drug Discov 3, 711-715.

Lee, G., Papapetrou, E.P., Kim, H., Chambers, S.M., Tomishima, M. J., Fasano, C.A., Ganat, Y.M., Menon, J., Shimizu, F., Viale, A., et al. (2009). Modelling pathogenesis and treatment of familial dysautonomia using patient-specific iPSCs. Nature 461, 402-406.

Maehr, R., Chen, S., Snitow, M., Ludwig, T., Yagasaki, L., Goland, R., Leibel, R.L., and Melton, D.A. (2009). Generation of pluripotent stem cells from patients with type 1 diabetes. Proc Natl Acad Sci U S A 106, 15768-15773.

Matsui, Y., Zsebo, K., and Hogan, B.L. (1992). Derivation of pluripotential embryonic stem cells from murine primordial germ cells in culture. Cell 70, 841-847.

Muotri, A.R., Nakashima, K., Toni, N., Sandler, V.M., and Gage, F.H. (2005). Development of functional human embryonic stem cellderived neurons in mouse brain. Proc Natl Acad Sci U S A 102, 18644-18648.

Nakagawa, M., Koyanagi, M., Tanabe, K., Takahashi, K., Ichisaka, T., Aoi, T., Okita, K., Mochiduki, Y., Takizawa, N., and Yamanaka, S. (2008). Generation of induced pluripotent stem cells without Myc from mouse and human fibroblasts. Nat Biotechnol 26, 101-106.

Newman, D.J., and Cragg, G.M. (2007). Natural products as sources of new drugs over the last 25 years. J Nat Prod 70, 461-477.

Norstrom, A., Akesson, K., Hardarson, T., Hamberger, L., Bjorquist, P., and Sartipy, P. (2006). Molecular and pharmacological properties of human embryonic stem cell-derived cardiomyocytes. Exp Biol Med 231, 1753-1762.

Obinata, M. (2007). The immortalized cell lines with differentiation potentials: their establishment and possible application. Cancer Sci 98, 275-283.

Okita, K., Nakagawa, M., Hong, H.J., Ichisaka, T., and Yamanaka, S. (2008). Generation of mouse induced pluripotent stem cells without viral vectors. Science 322, 949-953.

Pang, Y.Q., Li, W.X., Ma, R.L., Ji, W.D., Wang, Q., Li, D.C., Xiao, Y.M., Wei, Q., Lai, Y.D., Yang, P., et al. (2008). Development of human cell models for assessing the carcinogenic potential of chemicals. Toxicol Appl Pharmacol 232, 478-486. 
Park, I.H., Arora, N., Huo, H., Maherali, N., Ahfeldt, T., Shimamura, A., Lensch, M.W., Cowan, C., Hochedlinger, K., and Daley, G.Q. (2008). Disease-specific induced pluripotent stem cells. Cell 134, 877-886.

Patel, E., Wang, B., Lien, L.L., Wang, Y.C., Yang, L.J., Moreb, J.S., and Chang, L.J. (2009). Diverse T-cell differentiation potentials of human fetal thymus, fetal liver, cord blood and adult bone marrow CD34 cells on lentiviral Delta-like-1-modified mouse stromal cells. Immunology 128, e497-505.

Raya, A., Rodriguez-Piza, I., Guenechea, G., Vassena, R., Navarro, S., Barrero, M.J., Consiglio, A., Castella, M., Rio, P., Sleep, E., et al. (2009). Disease-corrected haematopoietic progenitors from Fanconi anaemia induced pluripotent stem cells. Nature 460, 53-59.

Rohwedel, J., Guan, K., Hegert, C., and Wobus, A.M. (2001). Embryonic stem cells as an in vitro model for mutagenicity, cytotoxicity and embryotoxicity studies: present state and future prospects. Toxicol In Vitro 15, 741-753.

Sartipy, P., Bjorquist, P., Strehl, R., and Hyllner, J. (2007). The application of human embryonic stem cell technologies to drug discovery. Drug Discov Today 12, 688-699.

Schneider, B.L., Seehus, C.R., Capowski, E.E., Aebischer, P., Zhang, C., and Svendsen, C.N. (2007). Over-expression of alphasynuclein in human neural progenitors leads to specific changes in fate and differentiation. Hum Mol Genet 16, 651-666.

Silva, J., Nichols, J., Theunissen, T.W., Guo, G., van Oosten, A.L., Barrandon, O., Wray, J., Yamanaka, S., Chambers, I., and Smith, A. (2009). Nanog is the gateway to the pluripotent ground state. Cell 138, 722-737.

Simon, L., Ekman, G.C., Kostereva, N., Zhang, Z., Hess, R.A., Hofmann, M.C., and Cooke, P.S. (2009). Direct transdifferentiation of stem/progenitor spermatogonia into reproductive and nonreproductive tissues of all germ layers. Stem Cells 27, 1666-1675.

Smith, A. (2009). Nanog Is the Gateway to the Pluripotent Ground State. Cell 138, 722-723.

Soldner, F., Hockemeyer, D., Beard, C., Gao, Q., Bell, G.W., Cook, E. G., Hargus, G., Blak, A., Cooper, O., Mitalipova, M., et al. (2009). Parkinson's disease patient-derived induced pluripotent stem cells free of viral reprogramming factors. Cell 136, 964-977.

Soucy, T.A., Smith, P.G., Milhollen, M.A., Berger, A.J., Gavin, J.M., Adhikari, S., Brownell, J.E., Burke, K.E., Cardin, D.P., Critchley, S., et al. (2009). An inhibitor of NEDD8-activating enzyme as a new approach to treat cancer. Nature 458, 732-736.

Sridharan, R., Tchieu, J., Mason, M.J., Yachechko, R., Kuoy, E., Horvath, S., Zhou, Q., and Plath, K. (2009). Role of the murine reprogramming factors in the induction of pluripotency. Cell 136, 364-377.

Stadtfeld, M., Nagaya, M., Utikal, J., Weir, G., and Hochedlinger, K. (2008). Induced pluripotent stem cells generated without viral integration. Science 322, 945-949.

Stout, J.T., and Caskey, C.T. (1988). The Lesch-Nyhan syndrome: clinical, molecular and genetic-aspects. Trends Genet 4, 175-178.

Sundstrom, L., Morrison, B., Bradley, M., and Pringle, A. (2005). Organotypic cultures as tools for functional screening in the CNS. Drug Discov Today 10, 993-1000.

Surani, M.A., Durcova-Hills, G., Hajkova, P., Hayashi, K., and Tee, W. W. (2008). Germ line, stem cells, and epigenetic reprogramming. Cold Spring Harb Symp Quant Biol 73, 9-15.
Takahashi, K., Tanabe, K., Ohnuki, M., Narita, M., Ichisaka, T., Tomoda, K., and Yamanaka, S. (2007). Induction of pluripotent stem cells from adult human fibroblasts by defined factors. Cell 131, 861-872.

Takahashi, K., and Yamanaka, S. (2006). Induction of pluripotent stem cells from mouse embryonic and adult fibroblast cultures by defined factors. Cell 126, 663-676.

Tanaka, T., Tohyama, S., Murata, M., Nomura, F., Kaneko, T., Chen, H., Hattori, F., Egashira, T., Seki, T., Ohno, Y., et al. (2009). In vitro pharmacologic testing using human induced pluripotent stem cellderived cardiomyocytes. Biochem Biophys Res Commun 385, 497-502.

Tanaka, T., Tohyama, S., Murata, M., Nomura, F., Kaneko, T., Chen, H., Hattori, F., Egashira, T., Seki, T., Ohno, Y., Koshimizu, U., Yuasa, S., Ogawa, S., Yamanaka, S., Yasuda, K., and Fukuda, K. (2009). In vitro pharmacologic testing using human induced pluripotent stem cell-derived cardiomyocytes. Biochem Biophys Res Commun 385, 497-502.

Tesar, P.J., Chenoweth, J.G., Brook, F.A., Davies, T.J., Evans, E.P., Mack, D.L., Gardner, R.L., and McKay, R.D. (2007). New cell lines from mouse epiblast share defining features with human embryonic stem cells. Nature 448, 196-199.

Theoharides, T.C., Kempuraj, D., Tagen, M., Vasiadi, M., and Cetrulo, C.L. (2006). Human umbilical cord blood-derived mast cells-A unique model for the study of neuro-immuno-endocrine interactions. Stem Cell Rev 2, 143-153.

Thomson, J.A., Itskovitz-Eldor, J., Shapiro, S.S., Waknitz, M.A., Swiergiel, J.J., Marshall, V.S., and Jones, J.M. (1998). Embryonic stem cell lines derived from human blastocysts. Science 282, 1145-1147.

Utikal, J., Polo, J.M., Stadtfeld, M., Maherali, N., Kulalert, W., Walsh, R.M., Khalil, A., Rheinwald, J.G., and Hochedlinger, K. (2009). Immortalization eliminates a roadblock during cellular reprogramming into iPS cells. Nature 460, 1145-1148.

Vallier, L., Touboul, T., Chng, Z., Brimpari, M., Hannan, N., Millan, E., Smithers, L.E., Trotter, M., Rugg-Gunn, P., Weber, A., et al. (2009). Early cell fate decisions of human embryonic stem cells and mouse epiblast stem cells are controlled by the same signalling pathways. PLos One 4, e6082.

van de Ven, C., Collins, D., Bradley, M.B., Morris, E., and Cairo, M.S. (2007). The potential of umbilical cord blood multipotent stem cells for nonhematopoietic tissue and cell regeneration. Exp Hematol 35, 1753-1765.

Vassilev, L.T., Vu, B.T., Graves, B., Carvajal, D., Podlaski, F., Filipovic, Z., Kong, N., Kammlott, U., Lukacs, C., Klein, C., et al. (2004). In vivo activation of the $\mathrm{p} 53$ pathway by small-molecule antagonists of MDM2. Science 303, 844-848.

Waterston, R.H., Lindblad-Toh, K., Birney, E., Rogers, J., Abril, J.F., Agarwal, P., Agarwala, R., Ainscough, R., Alexandersson, M., An, P., et al. (2002). Initial sequencing and comparative analysis of the mouse genome. Nature 420, 520-562.

Wright, L.S., Prowse, K.R., Wallace, K., Linskens, M.H.K., and Svendsen, C.N. (2006). Human progenitor cells isolated from the developing cortex undergo decreased neurogenesis and eventual senescence following expansion in vitro. Exp Cell Res 312, 2107-2120.

Yamada, T., Yoshikawa, M., Kanda, S., Kato, Y., Nakajima, Y., Ishizaka, S., and Tsunoda, Y. (2002). In vitro differentiation of 
embryonic stem cells into hepatocyte-like cells identified by cellular uptake of indocyanine green. Stem Cells 20, 146-154.

Ying, Q.L., Nichols, J., Chambers, I., and Smith, A. (2003). BMP induction of Id proteins suppresses differentiation and sustains embryonic stem cell self-renewal in collaboration with STAT3. Cell 115, 281-292.

Ying, Q.L., Wray, J., Nichols, J., Batlle-Morera, L., Doble, B., Woodgett, J., Cohen, P., and Smith, A. (2008). The ground state of embryonic stem cell self-renewal. Nature 453, 519-523.

Yu, J., Hu, K., Smuga-Otto, K., Tian, S., Stewart, R., Slukvin, II, and Thomson, J.A. (2009). Human induced pluripotent stem cells free of vector and transgene sequences. Science 324, 797-801.

Yu, J.Y., Vodyanik, M.A., Smuga-Otto, K., Antosiewicz-Bourget, J., Frane, J.L., Tian, S., Nie, J., Jonsdottir, G.A., Ruotti, V., Stewart, R., et al. (2007). Induced pluripotent stem cell lines derived from human somatic cells. Science 318, 1917-1920.
Zeh, K., Sanders, P., Londo, P., Crute, J.J., Pollok, B.A., and Whitney, M.A. (2003). Gain-of-function somatic cell lines for drug discovery applications generated by homologous recombination. Assay Drug Dev Technol 1, 755-765.

Zhang, S.C., Wernig, M., Duncan, I.D., Brustle, O., and Thomson, J. A. (2001). In vitro differentiation of transplantable neural precursors from human embryonic stem cells. Nature Biotechnology 19, 1129-1133.

Zhao, X.Y., Li, W., Lv, Z., Liu, L., Tong, M., Hai, T., Hao, J., Guo, C.L., Ma, Q.W., Wang, L., et al. (2009). iPS cells produce viable mice through tetraploid complementation. Nature 461, 86-90.

Zhou, H.Y., Wu, S.L., Joo, J.Y., Zhu, S.Y., Han, D.W., Lin, T.X., Trauger, S., Bien, G., Yao, S., Zhu, Y., et al. (2009). Generation of Induced Pluripotent Stem Cells Using Recombinant Proteins. Cell Stem Cell 4, 381-384. 